\title{
Synthesis of Marasin and 9-Me-Marasin, (Nona- and Deca-6,8-diyne-3,4-dlenol).
}

\author{
Wim de Graaf, Alike Smits, Jaap Boersma*, and Gerard van Koten \\ University of Utrecht, Laboratory of Organic Chemistry, Department of \\ Metal- mediated Synthesis, Padualaan 8, $3584 \mathrm{CH}$ Utrecht, THE \\ NETHERLANDS.
}

Wiel P. M. Hoekstra

University of Utrecht, Department of Molecular Cell-Biology, Padualaan 8, 3584 CH Utrecht, THE NETHERLANDS.

(Received in UK 17 Augusl 1988)

\begin{abstract}
Pentadienol was protected with ethyl vinyl ether and regloselectively $(70 \%)$ deprotonated at the terminal position by treatment with BuLi in THF at low temperature. Starting from the so obtained lithlum compound, Marasin (nona-6,8-diyne-3,4-dienol) (1a) and 9-Me-Marasin (deca-6,8-diyne-3,4-dienol) (1b) were prepared by two metal-mediated synthetic routes. Route A involves transmetallation of the llthium compound with LiCuBr 2 , followed by reaction with $\mathrm{Me}_{3} \mathrm{Sl}-\mathrm{C}=\mathrm{C}-\mathrm{C}=\mathrm{C}-\mathrm{I}$ or $\mathrm{Me}-\mathrm{C}=\mathrm{C}-\mathrm{C}=\mathrm{C}-1$. Route $\mathrm{B}$ involves transmetallation with $\mathrm{ZnCl} 2$ * followed by a palladlum-catalyzed coupling reaction with $\mathrm{Me} 3 \mathrm{Sl}-\mathrm{C}=\mathrm{C} \cdot \mathrm{C}=\mathrm{C}-\mathrm{Br}$ or $\mathrm{Me}-\mathrm{C}=\mathrm{C}-\mathrm{C}=\mathrm{C}-\mathrm{Br}$. Before removal of the protecting groups the yield of $\mathrm{C}-\mathrm{C}$ coupled products, $\mathrm{Me} 3 \mathrm{SI}-\mathrm{C}-\mathrm{C}-\mathrm{C}=\mathrm{C}-\mathrm{CH}-\mathrm{C}=\mathrm{CH}-\mathrm{CH}_{2} \mathrm{CH}_{2} \mathrm{OCH}(\mathrm{Me}) \mathrm{OEt}$ and $\mathrm{Me}-\mathrm{C}=\mathrm{C}-\mathrm{C}=\mathrm{C}-\mathrm{CH}-\mathrm{C}=\mathrm{CH}-\mathrm{CH}_{2} \mathrm{CH}_{2}$ $\mathrm{OCH}(\mathrm{Me}) \mathrm{OEt}(6 \mathrm{a}$ and $6 \mathrm{~b})$ was $95 \%$ va route $A$. Route $\mathrm{B}$ afforded (6a) and for $(6 \mathrm{~b})$ in $75 \%$ and $50 \%$ yield, respectively. After removal of the trimethylsilyl group with $\mathrm{AgNO}_{3}$ and the acetal group with trace of acid, (1a) and (1b) were obtained by route $A$ in $20 \%$ and $65 \%$ overall yleld, respectively, and by route $B$ in $13 \%$ and $30 \%$ overail yield, respectively. The antiblotic activity of both compounds was tested against Staphylococcus aureus and the MIC (Minimal Inhiblting Concentration) for Marasin was $0.2 \mu \mathrm{g} / \mathrm{ml}$. 9-Me-marasin was not active suggesting that the free acetylene function of the allenediyne is essential for the antibiotic activity.
\end{abstract}

Introduction. (-)-Marasin (nona-6,8-diyne-3,4-dienol) was isolated in 1959 by Bendz ${ }^{1}$ from the culture fluid of Marasmius ramealis as the active antibiotic component against Staphylococcus aureus. It was the first naturally occurring allene to be isolated and an example of a class of compounds, produced by micro-organisms, containing the allene-diyne system ${ }^{2}$ (fig. 1). The allene moiety of Marasin is chiral and both the $(-)$ - and the (+)-enantiomers occur in nature. The $(+)$-enantiomer was isolated later from a different source ${ }^{3}$ and appeared to have similar antibiolic activity.

$$
\mathrm{RC} \equiv \mathrm{C}-\mathrm{C} \equiv \mathrm{C}-\mathrm{CH}=\mathrm{C}=\mathrm{CH}-\left(\mathrm{CH}_{2}\right)_{n}-\mathrm{OH} \quad \mathrm{n=1-4}
$$

Figuret. Examples of allene-diyne antibiotics.

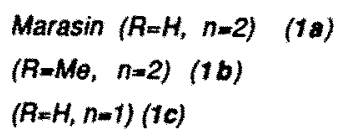

\section{Figure1. Examplos of allene-diyne antibiolics.}

In spite of the apparent simplicity of these linear compounds, aimost nothing is known about their antibiotic activity. This lack of interest is most probably due to the instablity and the inherent difficulties in the synthests of the allene-diyne system.

These difficulties are reflected in the synthetic studies of Marasin which are published up to now, that are all based on regiospecific reduction of an ene-triyne alcohol 4 . This method suffers from overreduction leading to low yields $(0-11 \%)$ and problems in product separation. Moreover, the products were only qualitatively characterized (u.v. and i.r. spectroscopy). 
A more straightforward method for the preparation of substituted allenes is a metal-mediated carbon-carbon coupling reaction 5 . In this way the $\mathrm{C}_{8}$-homologue of Marasin (fig. $1, n=1$ ) was prepared by Landor ef al. 6 using a copper-catalyzed coupling reaction of an acelylene with a bromoallene and by Vermeer ot ai 7 , using a palladium-catalyzed propargylic 1.3-substitution (scheme 1).

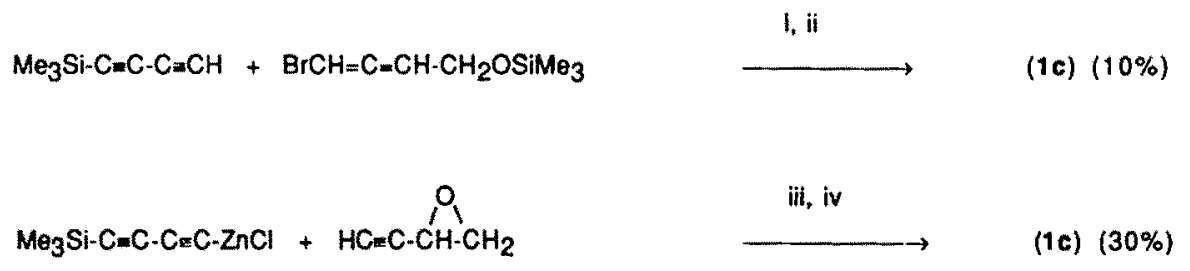

Scheme 1. Reagents: i, Bu3 $\mathrm{N}, \mathrm{CuBr} ;$ ii, $\left.\mathrm{OH}^{-} / \mathrm{MeOH} ; \mathrm{lii}, 5 \% \mathrm{Pd}_{(\mathrm{PPh}}\right)_{4} ; \mathrm{w}, \mathrm{AgNO}_{3}, \mathrm{NaCN}$.

'Umpolung' of this method involves reaction of an altenyl-metal reagent, which can be easily obtained from a terminal allene ${ }^{11}$, with an organic halide, $R \times(e q, 1)^{8}$.

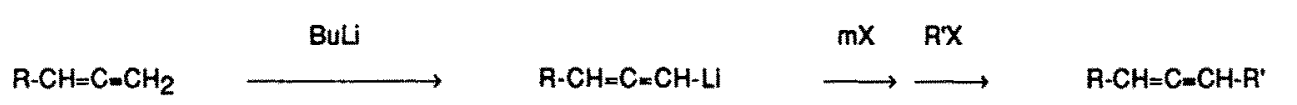

Because functionally protected 3,4-pentadienol (eq. 1, $\mathrm{R}=\mathrm{CH}_{2} \mathrm{CH}_{2} \mathrm{OCH}(\mathrm{Me}) \mathrm{OEf}$ ) can be easily deprotonated, with BuLi, mainly at the terminal position, we used the reaction deptcted in eq. 1 for the synthesis of racemic Marasin and its 9-Me homologue. The advantage of this method, in which the tragile allene-diyne unit is made by a mild metal-mediated C.C coupling reaction, is the reduced possibility of isomerisation, reduction or polymerisation of the unsaturated system.

For a check of the so obtained natural antiblotics the antibiotic activity of both Marasin and 9-Me-Marasin was tested against Staphytococous aurous.

\section{RESULTS AND DISCUSSION.}

The alcohol function of 3,4-pentadienol was protected with ethyl vinyl ether, giving acetal (2), which was treated with BuLi in THF at -50 to $-60^{\circ} \mathrm{C}$ (see scheme 2). Ethyl vinyl ether was chosen as protecting group because it is easy available, stable in the presence of strong base and can be acid-catalyzed removed by methanol. The latter is important because Marasin is known to be rapidly isomerised by base ${ }^{12}$. The starting compound (2), when freshly prepared, had a constant boiling point and the 1 H-NMR-spectrum showed a triplet and a quartet for the $\mathrm{OCH}_{2}$-groups. However, after storage for months or in the presence of a trace of acid, exchange of the acetal function occurs, forming a mixture of $(\mathrm{EIO})_{2} \mathrm{CHMe}, \mathrm{CH}_{2}=\mathrm{C}=\mathrm{CH}-\mathrm{CH}_{2} \mathrm{CH}_{2} \mathrm{OCH}(\mathrm{Me}) \mathrm{OEt}$ and $\left(\mathrm{CH}_{2}=\mathrm{C}=\mathrm{CH}-\mathrm{CH}_{2} \mathrm{CH}_{2} \mathrm{O}_{2} \mathrm{CHMe}\right.$. This exchange causes a complicated pattern for the $\mathrm{OCH}_{2}$-groups in the ${ }^{1} \mathrm{H}$-NMR spectra and three GC-peaks.

The regioselectivity of the lithiation was checked by deuteriolysis of the mixture obtained after the addilion of BuLi to (2) in THF at about -50 to $-60^{\circ} \mathrm{C}$. GCMS analysis of the deuteriolysis product of (2) with Buli showed that an extra isomer was formed with about the same mass spectrum as the main product and that peaks due to the $\mathrm{C}_{5}$-fragment of both isomers were increased by one mass number compared with (2). The proton at the 3-position of the 3,4-pentadienyl fragment of (2) appeared in the ${ }^{1}$ H-n.m.r. spectrum as a virtual quintet due to coupling with a comparable coupling constant with both the terminal (5-) protons and the protons at the 2-positlon. After lithiation and deuteriolysis of (2) a quartel was observed for the proton at the 3-position, Indicating that one hydrogen is replaced by a deuterium. However $30 \%$ of its intensity was lost, which means that also a part of the hydrogen of the 3-position is lost. The regloselectivity of the lithiation, based on integration of the signal of the proton at the 3-position, was not dependent on the batch of (2). Even excess of BuU has no influence on the regiospecilicity of the reaction. 


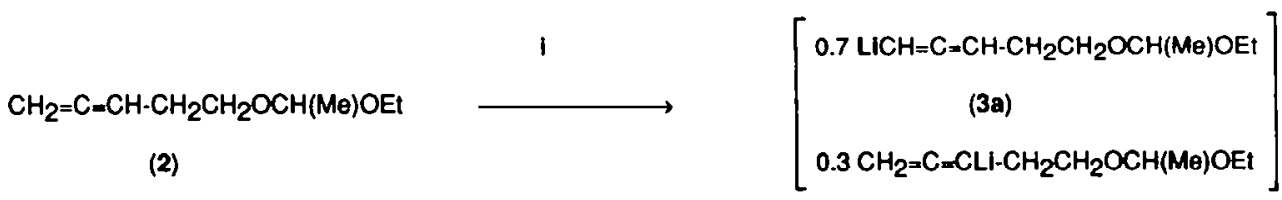

(3b)

ii

\section{$0.7 \mathrm{DCH}=\mathrm{C}=\mathrm{CH}-\mathrm{CH}_{2} \mathrm{CH}_{2} \mathrm{OCH}(\mathrm{Me}) \mathrm{OEt}+$}

(4a)
$0.3 \mathrm{CH}_{2} \mathrm{D}-\mathrm{CE}=\mathrm{C}-\mathrm{CH}_{2} \mathrm{CH}_{2} \mathrm{OCH}(\mathrm{Me}) \mathrm{OEt}$

(4b)

Scheme 2. Reagents: $i$, BuLiTHF $\left(-60^{\circ} \mathrm{C}\right) ;$ ii, $\mathrm{D}_{2} \mathrm{O}$.

The ${ }^{13} \mathrm{C}$-spectrum of the deuteriolysis product of (2) with BuLi showed a triplet at $874.94 \mathrm{ppm}$, due to ${ }^{13} \mathrm{C}$ - D coupling, replacing a singlet at the same chemical shift for the ${ }^{13} \mathrm{C}$-spectrum of (2). This signal was attributed to the terminal carton. The only other signal with a ${ }^{13} \mathrm{C}-\mathrm{D}$ coupling, except the solvent $\left(\mathrm{CDCl}_{3}\right)$ was found at $\delta 3.40 \mathrm{ppm}$. This low shift value can almost only be attributed to a $\mathrm{CDH}_{2} \mathrm{C}=\mathrm{C}$ - group. The formation of a small amount of (4b) is in agreement with a small multiplet observed at $\delta 1.76 \mathrm{ppm}$ in the $1 \mathrm{H}-\mathrm{n} . \mathrm{m} . \mathrm{r}$. spectrum. The formation of this compound can be thought arising from (3b), if $\mathrm{D}_{2} \mathrm{O}$ attacks the terminal position with simultanous 1,3-shift of a double bond, giving (4b). This feature also explaines the decrease in intensity of the proton in the 3-position in the ${ }^{1}$ H-n.m.r. spectrum of (4a).

The allenyllithium compound (3a) (scheme 2), although contaminated with (3b), is a suitable precursor for preparing the copper and zinc compounds (5 and 6). necessary for carbon-carbon coupling reactions (see scheme 3). Treatment of the copper compound (5) with iodo(trimethylsilyi)butadiyne or 1-iodopenta-1,3-diyne gave the functionally protected precursors (7a) and (7b), respectively, in very good yields (95\%). The $1 \mathrm{H}$-NMR spectra of (7a) and (7b) showed a Iriplet at $4.95 \mathrm{ppm}$, corresponding to about $20 \%$ contamination with isomers, which contain the MeC=C-C=C-resp. $\mathrm{Me}_{3} \mathrm{SiC} \equiv \mathrm{C}-\mathrm{C} \equiv \mathrm{C}$ - group in the 3-position. The formation of these isomers is in agreement with the contamination of (3a) with (3b) (scheme 2).

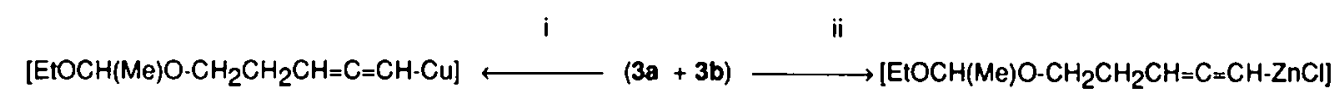

(5)

route A

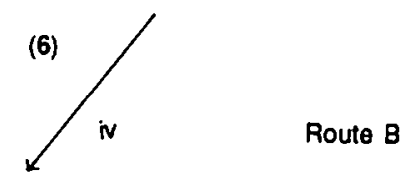

$\mathrm{R}-\mathrm{C}=\mathrm{C}-\mathrm{C}=\mathrm{C}-\mathrm{CH}=\mathrm{C}=\mathrm{CH}-\mathrm{CH}_{2} \mathrm{CH}_{2} \mathrm{OCH}(\mathrm{Me}) \mathrm{OEt}$

$$
\begin{array}{ll}
\text { (7a): } R=M e_{3} S i & \{95 \% \text { from (5); } 75 \% \text { from (6)\} } \\
& (7 b): R=M e \quad\{95 \% \text { from (5); } 50 \% \text { from (6)\} } \\
\text { v. vi } &
\end{array}
$$

$\mathrm{R}-\mathrm{C}=\mathrm{C}-\mathrm{C}=\mathrm{C}-\mathrm{CH}=\mathrm{C}=\mathrm{CH}-\mathrm{CH}_{2} \mathrm{CH}_{2} \mathrm{OCH}(\mathrm{Me}) \mathrm{OEt}$

(1a): $R=H \quad\{20 \%$ from (5); $13 \%$ from (6) $\}$

(1b): $R=M e ~\{65 \%$ from (5); $30 \%$ from (6) $\}$

Scheme 3.Reagents: i, LiCuBr 2 ; ii, ZnCl2; iii, R-C-C-C-C-I; iv, R-C-C-C-C-Br/Pơ-cat.; v, MeOH/H+; vi, (7a) : $\mathrm{Ag}^{+} / \mathrm{CN}^{-}$.

A palladium-calalyzed reaction of zinc compound (6) with bromo(trimelhylsilyl)butadiyne or 1-bromo-1,3-pentadiyne also resulted in the tormation of (7a) and (7b) although the yields were lower (75\% and $50 \%$, resp.) than in the copper-mediated reaction. The complex $\mathrm{PdCl}_{2}(\mathrm{PN})^{9}$ (see fig. 2) was used as catalyst although $\mathrm{Pd}\left(\mathrm{PPh}_{3}\right)_{4}$ worked almost as well. The palladium catalyzed reactions were complicated by homo-coupling and by 
formation of black polymers. Because a considerable amount $(30 \%)$ of 2,4,6,8-decatetrayne was found in the reaction of (6) with $\mathrm{MeC}=\mathrm{C}-\mathrm{C}=\mathrm{C} \cdot \mathrm{Br}$, the lower ylelds must be ascribed mainly to homo-coupling. A similar bis(trimethylsilyl)octatetrayne was however not found. It is probably so instable that it completely decomposes, as indicated by the black reaction mixture. The formation of black reaction mixtures and loss of yield was more apparent when iodo(trimethylsilyl)butadiyne and $\mathrm{Pd}\left(\mathrm{PPh}_{3}\right)_{4}$ were used. In an attempt to prepare optical enriched Marasin the coupling reaction of (6) with bromo(trimethyisilyl)butadiyne was carried out with $\mathrm{PdCl}_{2}\left[(\mathrm{R}, \mathrm{S})\right.$-PPFA] ${ }^{10}$ (See fig. 2) as catalyst. About the same yleld of Marasin was obtained as in the reaction catalyzed by $\mathrm{PdCl}_{2}(\mathrm{PN})$, but disappointingly the enantiomeric excess, determined by comparing the rotations of synthetic with natural Marasin 1 , was very low $(0.5$ $\%)$.

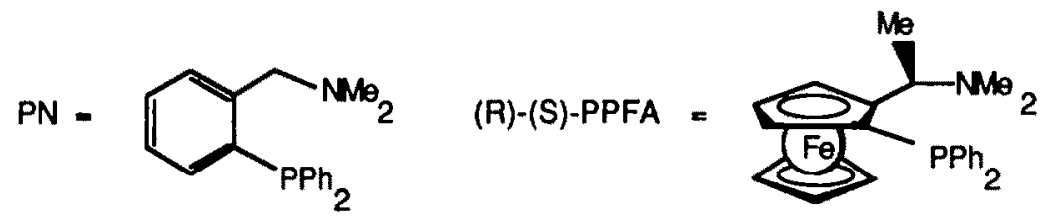

Figure 2. PN = O-diphenylphosphine-N,N-dimethylbenzylamine; (R,S)-PPFA = (R)-1-N,N-dimethylamino-1$[(S)$-2-diphenylphosphinoferrocenyl]ethane.

Compounds (7a) and (7b) were purified by column chromatography and obtained as yellow oils. The yields given above were based on the chromatographed products.

Removal of the trimethylsilyl group from (7a) was performed with silver nitrate 13 in methanol. A yellow-white insoluble sitver compound was formed, which was decomposed with NaCN. During this reaction sequence the acetal group was also removed and Marasin was obtained without need of a second deprotection step. Although the greater pant decomposed, due to the instability of the compound, this method proved to be very valuable because Marasin is very rapidly isomerized by base ${ }^{12}$ and indeed other methods for removing a trimethylsilyl group from an acetylene, like base in $\mathrm{MeOH}$ or fluoride in DMF, failed. Marasin was obtained as an yellow-brown oil. It is very unstable when pure and explodes on heating. It should be stored as a dilute $\left(\mathrm{k} \%\right.$ solution in ethanol at low temperature $\left(-30^{\circ} \mathrm{C}\right)$. 9-Me Marasin is markedly more thermally stable and can be stored undiluted for weeks at $-30^{\circ} \mathrm{C}$ without significant decomposition.

The properties of Marasin (1a) its instability in pure form and its relative stability in dilute solution, are in agreement with the description in the literature $1,3,4$. Although (1a) and (1b), prepared by route $A$ were contaminated with isomers, arising from lithium compound (3b), route B afforded (1a) and (1b) contaminated only with about $20 \%$ of starting compound (2).

The antibiotic activity of both allenediynes (1a and 1b) was tested against Staphlyococcus aureus. Marasin (1a) inhibited the cell growth and the minimal inhibiting concentration was $0.2 \mu g / \mathrm{mL}$. The antiblotic action was clearly of a bacteriostatic nature and even up to a concentration of $1.4 \mu \mathrm{g} / \mathrm{mL}$ the number of living cells did not decrease. 9 Me-Marasin (1b), however, was not active at all up to concentrations of $9 \mu \mathrm{g} / \mathrm{mL}$, suggesting that the terminal acetylene hydrogen is essential for the antibiotic activity.

\section{EXPERIMENTAL}

${ }^{1} \mathrm{H}$-n.m.r. spectra were recorded on Varian EM 360 and EM 390, and Bruker AW 80 spectrometers. ${ }^{13}$ C-n.m.r. spectra were recorded on a Bruker AC 200 spectrometer. I.r. spectra were recorded on a Perkin-Elmer 457 spectrometer and u.v. spectra on a Perkin-Elmer 552 spectrometer. THF was distilled from LiAlH 4 or sodium/benzophenone. Butyllithium was used as the commercially available solution in hexane (1.5-1.6 M). CuBr was prepared by reduction of an squous $\mathrm{Cu}(\mathrm{II})$-solution with $\mathrm{SO}_{2}$ in the presence of bromide. Commerclally anhydrous $\mathrm{ZnCl} 2(98+\%)$ was drled at $2000^{\circ} \mathrm{Cl} 0.1$ $\mathrm{mmHg}$, dissolved in THF and used as $1 \mathrm{M}$ solution.

All preparations were conducted in an atmosphere of dry nitrogen, although work-up and product isolation were pertormed in air.

Preparation of acetaldehyde 3,4-pentadienyl ethyl acetal, (2). Penta-3,4-dienol (8.1 g; 0.1 mol), prepared following the procedure given in ref. 14 , was added stowly to $20 \mathrm{ml}$ of ethyl vinyl ether containing $50 \mathrm{mg}$ of $\rho$ - toluenesulfonic acid. During the addition the mixture was stirred and cooled in ice. After the addition the stirring was continued for one hour and the mixture was then washed with $20 \mathrm{ml}$ of water containing $1 \mathrm{~g}$ of $\mathrm{Na}_{2} \mathrm{CO}_{3}$. The organic layer was separated and 
subsequently dried over $\mathrm{MgSO}_{4}$. After evaporation of the solvent the residue was distilled at reduced pressure. 8.p. 75-80 ${ }^{\circ} \mathrm{C} / 15 \mathrm{mmHg}$. Yleld (10.3 g, 80\%).

$\delta_{H}\left(\mathrm{CCl}_{4}\right) 1.05\left(3 \mathrm{H}, \mathrm{t}, \mathrm{CH}_{3} \mathrm{CH}_{2} \mathrm{O}-\right), 1.15\left(3 \mathrm{H}, \mathrm{d}, \mathrm{CH}_{3} \mathrm{CH}_{2}-2.21\left(2 \mathrm{H}, \mathrm{q}\right.\right.$ of t, $\left.-\mathrm{CH}_{2} \mathrm{CH}=\right), 3.38$ (2 H, q. $\left.-\mathrm{OCH}_{2} \mathrm{CH}_{3}\right), 3.38\left(2 \mathrm{H}, \mathrm{t},-\mathrm{OCH}_{2} \mathrm{CH}_{2}-\right.$ ), 4.50-4.70 (3 H, m, $-\mathrm{CH}=\mathrm{C}-\mathrm{CH}_{2}$ and $-\mathrm{OCHM}-\mathrm{O}-$ ), 5.00 (1 $\mathrm{H}$, quintet, $\left.\mathrm{CH}_{2}=\mathrm{C}=\mathrm{CH}-\mathrm{CH}_{2}\right)$.

Lithiation and deuteration of acetaldehyde 3,4-pentadienyl ethyl acetal, (2). $0.010 \mathrm{Mol}$ of the protected allenic alcohol was dissolved in $20 \mathrm{ml}$ of THF and cooled $10-60^{\circ} \mathrm{C}$. $0.010 \mathrm{Mol}$ of BuLi in hexane was added dropwise, keeping the temperature below $-55^{\circ} \mathrm{C}$. A yellow solution was formed. A solution of $1 \mathrm{~mL}$ of $\mathrm{D}_{2} \mathrm{O}$ in $5 \mathrm{ml}$ of THF was then added to the yellow solution upon which the solution decolourized. After shaking the latter mixture with saturated $\mathrm{NH}_{4} \mathrm{Cl}$ solution, the organlc layer was separated and the water layer was extracted three times with diethyl ether. The organic tractions were combined, dried over $\mathrm{MgSO}_{4}$ and evaporated at reduced pressure, leaving $1.3 \mathrm{~g}(85 \%)$ of an oil. $20 \mathrm{ml}$ of methanol and $50 \mathrm{mg}$ of $p$ - toluenesulfonic acid were added and the mixture was stirred for one hour. Subsequently the mixture was poored in $50 \mathrm{ml}$ of water containing $\mathrm{NaHCO}_{3}$ and extracted three times with $10 \mathrm{ml}$ portions of diethyl ether. The fractions were dried over $\mathrm{MgSO}_{4}$ and evaporated at reduced pressure, leaving $0.65 \mathrm{~g}(80 \%)$ of an oil. $\delta_{\mathrm{H}}\left(\mathrm{CCl}_{4}\right) 1.66(0.5 \mathrm{H}, \mathrm{m}$, $\mathrm{CH}_{2} \mathrm{DCmC}$ ), $2.20\left(2 \mathrm{H}, \mathrm{q}\right.$ of d, $\left.-\mathrm{CH}_{2} \mathrm{C}=3\right), 3.62\left(2 \mathrm{H}, \mathrm{t},-\mathrm{OCH}_{2} \mathrm{CH}_{3}\right), 4.64(1.0 \mathrm{H}, \mathrm{m},-\mathrm{CH}=\mathrm{C}=\mathrm{CHD}), 5.20$ (0.7 H, q. $\left.-\mathrm{CH}_{2} \mathrm{CH}=\mathrm{C}=\mathrm{CHD}\right) .8 \mathrm{C}\left(\mathrm{CDCl}_{3}\right) 3.4\left(\mathrm{t}, \mathrm{CH}_{2} \mathrm{DC}=\right), 31.0$ (s, $\mathrm{CH}_{2} \cdot \mathrm{CH}=$ ), 61.7 (s, $\left.\mathrm{CH}_{2} \mathrm{OH}\right), 74.1$ (t, $\mathrm{CHD}=\mathrm{C}=$ ), 86.1 (s, $=\mathrm{CH}-\mathrm{CH}_{2}-\mathrm{)}, 209.1(=\mathrm{C}=)$.

Preparation of the halogenobutadiynes. Cautlon: Heating the 1-halogen substituted diynes can cause violent explosions. A safety shield should be used during distillation.

Trimethylsilyl-butadiyne ${ }^{14}$ and pentadiyne ${ }^{13}$ were prepared following literature procedures. The butadiyne (0.1 mol) in $100 \mathrm{~mL}$ of diethyl ether was treated with $65 \mathrm{ml}$ of $1.6 \mathrm{M}$ BuLi in hexane, keeping the temperature below - $40{ }^{\circ} \mathrm{C}$. Pure $\mathrm{Br}_{2}(0.1 \mathrm{~mol})$, or a solution of $\mathrm{l}_{2}(0.1 \mathrm{~mol})$ in diethyl ether, was added dropwise, still keeping the temperature below $40^{\circ} \mathrm{C}$. Work-up was performed by shaking the reaction mixture with a solution of $\mathrm{NH}_{4} \mathrm{Cl}$ and $\mathrm{Na}_{2} \mathrm{~S}_{2} \mathrm{O}_{3}$ in water. Evaporation of the solvents gave the crude compounds. The bromodiynes were purified by distillation. A water bath was used with a maximum temperature of $80{ }^{\circ} \mathrm{C}$. 1-10do-1,3-pentadiyne was purified by bulb to bulb sublimation and 1-iodo-4-trimethylsilyl-1.3. butadiyne was recrystallized from diethyl ether/pentane.

1-bromo-1,3-pentadiyne. M.p. $0.5^{\circ} \mathrm{C}$, b.p. $46^{\circ} \mathrm{C} / 18 \mathrm{mmHg}, \mathrm{m} / 2142 / 144\left(\mathrm{M}^{+}\right), \delta_{\mathrm{H}}(\mathrm{CCl} / 4) 1.95$ (s).

1-bromo-4-trimethylsilyl-1,3-butadiyne. M.p. $0.5{ }^{\circ} \mathrm{C} ;$ bp. $42^{\circ} \mathrm{C} / 2 \mathrm{mmHg}, \mathrm{m} / 2200 / 202\left(\mathrm{M}^{+}\right), \delta_{\mathrm{H}}\left(\mathrm{CCl}_{4}\right) 0.22(\mathrm{~s})$.

1-iodo-1,3-pentadiyne. M.p. $36^{\circ} \mathrm{C}, \mathrm{m} / \mathrm{z} 190\left(\mathrm{M}^{+}\right), \delta_{\mathrm{H}}\left(\mathrm{CCl}_{4}\right) 1.95(\mathrm{~s})$.

1-iodo-4-trimethylsilyl-1,3-butadiyne. M.p. $70^{\circ} \mathrm{C}, \mathrm{m} / 2248\left(\mathrm{M}^{+}\right), \delta_{H} 0.22$ (s).

Copper-promoled coupling-reaction. To a solution of $0.010 \mathrm{~mol}$ acetaldehyde lithio-3,4-pentadienylethylacetal (3a + 3b), prepared as described above, was added $0.010 \mathrm{~mol}$ of $\mathrm{LiCuBr}_{2}$, prepared by dissolving $1.56 \mathrm{~g}$ of $\mathrm{CuBr}$ and 0.010 mole of $\mathrm{LiBr}$ in $5 \mathrm{~mL}$ of THF, keeping the temperature below $-50^{\circ} \mathrm{C}$. Then Mes $\mathrm{Si}-\mathrm{C}=\mathrm{C}-\mathrm{C}=\mathrm{C}-1$ (0.010 mol) or $\mathrm{Me}-\mathrm{C}=\mathrm{C} \cdot \mathrm{C}=\mathrm{C}-1(0.010 \mathrm{~mol})$ was added and the temperature was allowed to rise slowly to $0^{\circ} \mathrm{C}$. After stirring for one hour at $0^{\circ} \mathrm{C}$ the mixture was poured in saturated aquous $\mathrm{NH}_{4} \mathrm{Cl}$ and shaken. Small amounts of $\mathrm{NaCN}$ were added to dissolve insoluble copper salts. The organic layer was separated and evaporated to dryness. The residue was chromatographed over a column $(20 \mathrm{~cm} ; 2 \mathrm{~cm}$ ) charged with florisil and eluted with pentane. Yleld $95 \%$.

Palladium-catalyzed coupling-reaction. To the solution of acetaldehyde lithio-3,4-pentadienyl ethyl acetal (3a $+3 \mathrm{~b})$, prepared as described above, was added $0.012 \mathrm{~mol}$ of $\mathrm{ZnCl}_{2}$ as a $1 \mathrm{M}$ solution in THF, keeping the temperature below $-55^{\circ} \mathrm{C}$. Finally, $0.010 \mathrm{~mol}$ of $\mathrm{Me}_{3} \mathrm{Si}-\mathrm{CaC}-\mathrm{C}=\mathrm{C}-\mathrm{Br}$ or $\mathrm{Me}-\mathrm{C}=\mathrm{C}-\mathrm{C}=\mathrm{C}-\mathrm{Br}$ and $50 \mathrm{mg}$ of $\mathrm{PdCl}_{2}(\mathrm{PN})$ or $0.5 \mathrm{~g}$ of $\mathrm{Pd}(\mathrm{PPh})_{4}$ were added. After warming to room temperature the mixture was stirred tor six hours. Then the mixture was shaken with $100 \mathrm{ml}$ of satured aquous $\mathrm{NH}_{4} \mathrm{Cl}$. The organic layer was separated and the solvent removed in vacuo. The products were purified by column chromatography as described for the copper-promoted reaction and obtained as light yellow oils (2.0 g. and $1.1 \mathrm{~g}$, resp.). From the reaction with $\mathrm{MeC}=\mathrm{C}-\mathrm{C}=\mathrm{C}-\mathrm{Br}$ was also isolated $0.5 \mathrm{~g}$ of a solid, which was identified as deca-2,4,6,8-tetrayne. $M / z 126\left(\mathrm{M}^{+}\right), \delta_{\mathrm{H}}\left(\mathrm{CCl}_{4}\right) 1.95$ (s).

Removal of the protecting groups of (7a) and (7b).- The yield of (7a) or (7b), obtained from the copper-promoted or the palladium-catalyzed coupling reaction, was dissolved in $30 \mathrm{ml}$ methanol. The trimethylsilyl group of (7a) was removed by adding $2 \mathrm{~g}$ of $\mathrm{AgNO}_{3}$ in $2 \mathrm{ml}$ water to the methanolic solution. Stirring was continued for one hour at $0^{\circ} \mathrm{C}$. during which a white suspension formed. Diethyl ether $(20 \mathrm{ml})$ was added in actvance in order to dissolve immediately the very unstable Marasin (1a) which was liberated by adding a solution of $3 \mathrm{~g} \mathrm{NaCN}$ in $50 \mathrm{~mL}$ of aqueous $\mathrm{NH}_{4} \mathrm{Cl}$. During this 
operation the acetal function of (7a) was removed simultanousty. The acetal functional group was removed by stirring the solution in methanol for one hour at $0^{\circ} \mathrm{C}$ with $50 \mathrm{mg}$ of $p$-toluenesultonic acid. The compounds were recovered by extracting three times with diethyl ether and the solvents were removed under reduced pressure $(0.1 \mathrm{mmHg}) \mathrm{keeping}$ the temperature at $0^{\circ} \mathrm{C}$. The residues were immediately taken up in a small amount of ethertpentane and dried over $\mathrm{MgSO}_{4}$. Chromatography over a column $(20 \mathrm{~cm}, 25 \mathrm{~mm} \emptyset)$ charged with $\mathrm{Al}_{2} \mathrm{O}_{3}$ (deactivated with $5 \% \mathrm{H}_{2} \mathrm{O}$ ) with ether/pentane (1:1), followed by pure diethyl ether gave Marasin or 9-Me-Marasin as yellow oils after evaporation of the solvents in vacuo $\left(0.1\right.$ torr) at a bath temperature of $5{ }^{\circ} \mathrm{C}$. The products (1a and 1b) of the copper-mediated route, showed triplets in the 1 H.NMR spectrum at 4.95 ppm, corresponding with contamination with about $20 \%$ of hepta- and octa-3-vinylidene-4,6-diynol, respectively. The only contaminant, when the palladium-catalyzed route was used was about $20 \%$ of the starting akcohol 3,4-pentadienol and a trace $(<5 \%)$ of its isomer penta-3-ynol, based on the ${ }^{1} \mathrm{H}-\mathrm{NMR}$ spectra.

A synthesis of Marasin via route $A$, carried out with $\mathrm{PdCl}_{2}[(\mathrm{R}, \mathrm{S})$-PPFA] as catalyst yielded (1a) in 13\% yield with $\left[\alpha_{D}\right]=-4^{\circ}(c-0.1$,ethanol), corresponding with an e.e. of $0.5 \%$.

Pure Marasin must be hand led very rapldly at low temperature $\left(<0{ }^{\circ} \mathrm{C}\right.$ ) and should be redissolved as quickly as possible because polymerisation proceeds within a few minutes at room temperature. Distillation was not possible since the compounds (1a and 1b) explode violently even upon slight heating.

Nona-6,8-diyne-3,4-dienol. U.v. $\lambda_{\max }(E \mathrm{OHH}) 277 \mathrm{~nm}(\log \mathrm{e}=4.06), 260 \mathrm{~nm}(4.13), 246 \mathrm{~nm}(4.01), 234 \mathrm{~nm}$ (3.89), and198 $\mathrm{nm}(4.38)$, i.r. $v_{\max }\left(\mathrm{CCl}_{4}\right) 3630(\mathrm{O} \cdot \mathrm{H}), 3315(=\mathrm{C} \cdot \mathrm{H}), 2215(\mathrm{C}=\mathrm{C}), 1950(\mathrm{C}=\mathrm{C}=\mathrm{C}), 1045 \mathrm{~cm}^{-1}$ (C-O), $\delta_{H}\left(\mathrm{CCl}_{4}\right) 2.27(1 \mathrm{H}, \mathrm{s}, \mathrm{H}-\mathrm{Cm}), 2.28\left(2 \mathrm{H}, \mathrm{q}\right.$ of d, $\left.-\mathrm{CH}_{2}-\mathrm{CH}_{m}\right), 2.7(1 \mathrm{H}$, br. s, $-\mathrm{OH}), 3.65(2 \mathrm{H}, \mathrm{t},-\mathrm{CH} 2 \mathrm{O})$, 5.25-5.75 (2 $\mathrm{H}, \mathrm{m},-\mathrm{CHw} \mathrm{C}=\mathrm{CH})$.

Deca-6,8-diyn-3,4-dienol. U.v $\lambda_{\max }(E t O H) 277 \mathrm{~nm}(\log \varepsilon=3.80), 262 \mathrm{~nm}(3.88), 247 \mathrm{~nm}(3.74), 234 \mathrm{~nm}$ (3.60), and $198 \mathrm{~nm}(3.94)$, l.r. $v_{\max }\left(\mathrm{CCl}_{4}\right) 3350(\mathrm{O}-\mathrm{H}), 2225(\mathrm{C}=\mathrm{C}), 1950(\mathrm{C}-\mathrm{C}-\mathrm{C}), 1045 \mathrm{~cm}^{-1}(\mathrm{C}-\mathrm{O})$, $\delta_{\mathrm{H}}\left(\mathrm{CCl}_{4}\right) 1.97\left(\mathrm{~s}, 3 \mathrm{H}, \mathrm{CH}_{3} \mathrm{Cm}\right.$ ), 2.27 ( $\mathrm{q}$ or d, 2H, $\left.2 \mathrm{H},-\mathrm{CH}_{2}-\mathrm{CH}_{\mathrm{m}}\right), 3.65\left(\mathrm{l}, 2 \mathrm{H},-\mathrm{CH}_{2} \mathrm{O}\right), 4.2$ (br. s, 1H, $-\mathrm{OH}$ ), 5.25-5.75 ( $m, 2 \mathrm{H},-\mathrm{CH}=\mathrm{C}-\mathrm{CH}-)$.

Minimal inhibiting concentration (MIC) determination.- Marasin (1a) or 9-Me-marasin (1b) were added in appropriate concentrations to liquified peptone-agar (peptone, $1 \%$; yeast extract, $0.5 \% ; \mathrm{Na}_{2} \mathrm{HPO}_{4} \cdot 2 \mathrm{H}_{2} \mathrm{O}, 1 \% ; \mathrm{Difco}$ agar $1.5 \%$ ) and plates were poured. Log-phase cells of Staphylococcus aureus were plated by streaking $0.1 \mathrm{~mL}$ of a diluted culture $\left(10^{3}\right.$ to $10^{4}$ cells per $\mathrm{mL}$ ). The plates were cultivated at $37^{\circ} \mathrm{C}$ and atter 24 hours scored for bacterial growth.

\section{Reterences}

1 G. Bendz, Arkiv for Kemi, 1959, 14, 305.

2 S. A. Landor, The Chemistry of the Allenes:, Academic Press, London, 1982, Ch. 7, Vol. III, and ref. cited therein.

3 R. C. Camble, A. Hirschberg, E. R. H. Jones, and G. Lowe, J. Chem. Soc., 1963, 4120.

4 (a) E. B. Bates, E. R. H. Jones, and M. C. Whiting, J. Chem. Soc. 1965, 1854; (b) F. Bohimann, P. Herbst, and H. Cleinig, Chem. Ber., 1961, 94, 948; (c) S. P. Landor, E. S. Pepper and J. P. Regan, J. Chem. Soc (C), 1967, 189; (d) S. P. Landor, B. J. Miller, J. P. regan, A. R. Tatchell, J. Chem. Soc., Perkin Trans. I, 1971, 557.

5 (a) K. Ruitenberg, H. Kleijn, C. J. Elsevier, J. Meijer, and P. Vermeer, Tetrahedron Lett. 1981, 22, 1451; (b) K. Ruitenberg. H. Kleijn, H. Westmijze, J. Meijer and P. Vermeer, Recl. Trav. Chim. Pays-Bas, 1982, 101, 405.

6 P. D. Landor, S. R. Landor and J. P. Leighton, Tetrahodron Lett., 1973, 1019.

7 H. Kleijn, J. Meijer, G. C. Overbeek, and P. Vermeer. Rect. Trav. Chim. Pays-Bas, 1982, $101,97$.

8 K. Ruitenberg, H. Kleijn, J. Meijer, E. A. Oostveen and P. Vermeer, J. Organomet. Chem., 1982, $224,399$.

9 W. de Graat, S. Harder, J. Boersma, J. Kanters and G. van Koten, J. Organomet. Chem. in press.

10 (a) T. Hayashi, M. Konishi, M. Fukushima, T. Mise, M. Kogotami, M. Tajka and M. Kumada, J. Am. Chem. Soc., 1982. 104,180; (b) T. Hayashi and M. Kumada, in 'Asymmetric Synthesis', Ac. Press, London, 1985, Vol. 5, Ch. 5, p. 147 and ref. cited therein.

11 (a) G. Linstrumelle, and D. Michelot, J. Chem. Soc., Chem. Commun., 1975, 561; (b) J.-C. Clinet, and G.

Linstrumelle, Tetrahedron Lett., 1978, 1137.

12 G. Bendz, Arkiv for Kemi, 1959, 14, 475.

13 L. Brandsma, 'Preparative Acetylenic Chemistry', Elseviers Scientific Publ. Co.. Amsterdam, 1971.

14 D.R.M. Walton and F. Waugh, J. Organomet. Chem., 1972, 37, 45. 